\author{
Г.І. Лагутін ${ }^{1}$, С.М. Хабоша ${ }^{1}$, В.О. Перепелиця ${ }^{1}$, I.І. Кулинич ${ }^{2}$, I.О. Солдатенко ${ }^{3}$ \\ ${ }^{1}$ Харківський національний університет Повітряних Сил ім. І. Кожедуба, Харків \\ ${ }^{2}$ Національний університет оборони Украӥни ім. I. Черняховського, Київ \\ ${ }^{3}$ Управління регулювання державної авіачії України, Київ
}

\title{
НАПРЯМИ УДОСКОНАЛЕННЯ ЗАСОБІВ МОНТТОРИНГУ ТЕХНІЧНОГО СТАНУ СИЛОВИХ КАБЕЛЬНИХ ЛІНІЙ СИСТЕМ ЕЛЕКТРОПОСТАЧАННЯ ВІЙСЬКОВИХ АЕРОДРОМІВ
}

В статті проведений аналіз причин погіршення технічного стану силових кабельних ліній, які виникають в системах електропостачання стаціонарних військових аеродромів, та існуючих засобів оцінки стану ізоляиії силових кабелів в умовах експлуатаџіiі. На підставі проведеного аналізу розглянуті перспективні засоби неруйнівного моніторингу технічного стану силових кабельних ліній систем електропостачання військових аеродромів, які сприяють підвищенню надійності функиіонування систем забезпечення польотів asiaụii.

Ключові слова: стачіонарний аеродром, системи електропостачання, силові кабельні лінії, моніторинг технічного стану.

\section{Вступ}

Постановка проблеми. Стаття створена в рамках магістерської роботи "Розробка засобів визначення технічного стану силових кабельних ліній систем електропостачання військових аеродромів, що залучаються для потреб ООС”. Надійне функціонування систем електропостачання військових аеродромів Повітряних Сил неможливе без стійкої роботи силових кабелів низької та високої напруги. В процесі експлуатації силові кабельні лінії (КЛ) піддаються комплексному впливу різних чинників, що може призвести до пошкодження кабелів при досягненні граничних значень характеристик ізоляції [1].

Для попередження аварій на КЛ і розробки стратегії щодо ремонту або заміни силових кабелів 3 небезпечними дефектами чи з виробленим ресурсом ізоляції необхідно мати достовірну інформацію про ï поточний технічний стан. Керівні документи, що діють на цей час, передбачають проведення тільки періодичних вимірювань та випробувань [2], які, з одного боку, дають тільки імовірнісну оцінку імовірності безвідмовної роботи силових КЛ в період між вимірюваннями (випробуваннями), а з іншого боку, можуть самі стати причиною виходу лінії з ладу. Щоб запобігти вказаним негативним наслідкам, необхідно дослідити напрями удосконалення засобів безперервного контролю технічного стану (моніторингу) силових КЛ. При експлуатації систем електропостачання (СЕП) військових аеродромів мають застосовуватися сучасні засоби неруйнівного моніторингу силових КЛ. Це дозволить підвищити надійність функціонування систем забезпечення польотів авіації стаціонарних аеродромів Повітряних Сил.

Аналіз останніх досліджень і публікацій. Аналіз систем електропостачання військових аеродромів показав, що для оцінки стану ізоляції силових кабелів в умовах експлуатації застосовуються різні методи випробувань та діагностики, в тому числі періодичні випробування випрямленою напругою або випробування змінною напругою наднизької частоти 0,1 Гц спеціальної форми “косинусний прямокутник” [3]. Величина випробувальної напруги перевищує величину робочої напруги кабелю в 2-6 разів, що може призвести до пробою ізоляції кабелю, який не мав небезпечних дефектів і в нормальних умовах міг би ще працювати певний час. В літературі [4-9] розглядаються сучасні способи та засоби періодичного та безперервного неруйнівного контролю технічного стану силових КЛ, однак можливість їх застосування для моніторингу високовольтних та низьковольтних кабелів систем електропостачання військових аеродромів до кінця не досліджена.

Тому актуальним є проведення досліджень, спрямованих на впровадження неруйнівних засобів визначення технічного стану силових КЛ для СЕП стаціонарних аеродромів Повітряних Сил.

Мета статті - Метою роботи $є$ дослідження напрямів удосконалення засобів моніторингу технічного стану силових кабельних ліній систем електропостачання військових аеродромів, спрямованих на підвищення надійності функціонування систем забезпечення польотів авіації. 


\section{Виклад основного матеріалу}

До складу систем електропостачання військових аеродромів входять силові КЛ високої (6-10 кВ) та низької (0,4 кВ) напруги [10]. В процесі експлуатації вони піддаються комплексному впливу електричного і теплового полів; зволоженню ізоляції; механічному старінню і пошкодженням внаслідок вібрації, впливу електродинамічних зусиль і механічних навантажень; хімічному старінню під впливом агресивних речовин. Під дією цих факторів відбувається місцеве зменшення електричної міцності внаслідок технологічних порушень, зволоження ізоляції, негерметичності свинцевої оболонки для кабелів 3 паперово-масляною ізоляцією, а також втрати герметичності захисної оболонки кабелю 3 полівінілхлоридною ізоляцією, термопластичного поліетилену або з ізоляцією зі зшитого поліетилену, процесів старіння ізоляції, порушення технології монтажу кабелю (ум'ятин кабелю, перегрівання під час паяння, неякісний монтаж ізоляції кінцевих муфт тощо), дій сторонніх осіб. Внаслідок цього в кабелях можуть утворюватися внутрішні пошкодження, які в подальшому можуть призвести до виходу кабелів 3 ладу. До таких пошкоджень можуть бути віднесені [11]: отвори в ізоляції зовнішньої оболонки кабелю; отвори в ізоляції внутрішньої оболонки кабелю; внутрішні порожнечі; різноманітні включення; тріщини в оболонці та ізоляторі; водяні “дерева” (тріщини, заповнені водою), а також водяні “містки”, що з'єднують поверхневі шари ізоляції з внутрішньою частиною кабелю; корозія оболонки; механічні руйнування ізоляції провідників (рис. 1).

На рис. 2 наведені приклади пошкоджень, які можуть виникати при монтажі силових кабельних ліній.

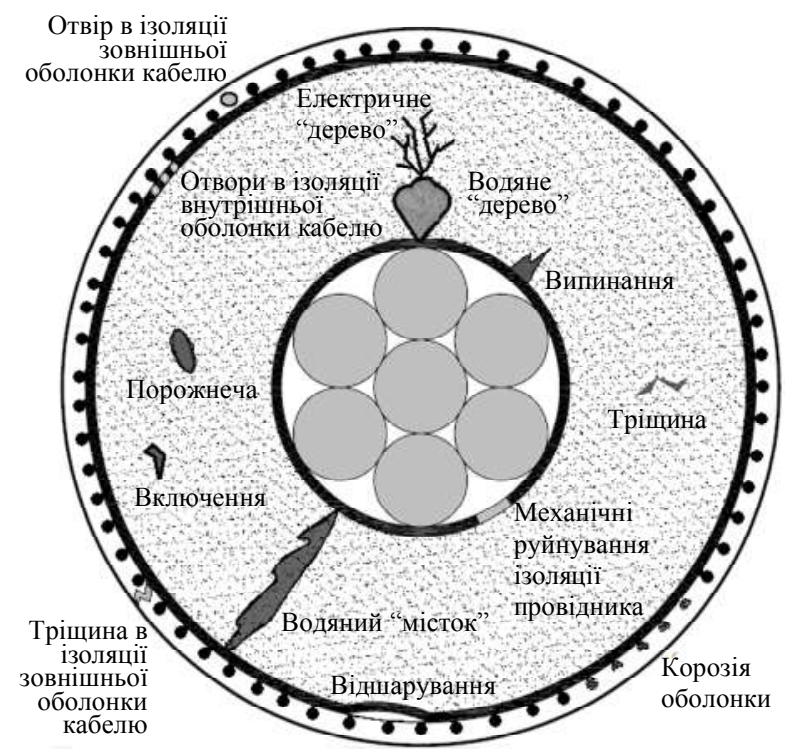

Рис. 1. Типові пошкодження кабелів з полімерною ізоляцією

Джерело: розроблено авторами за даними [11].

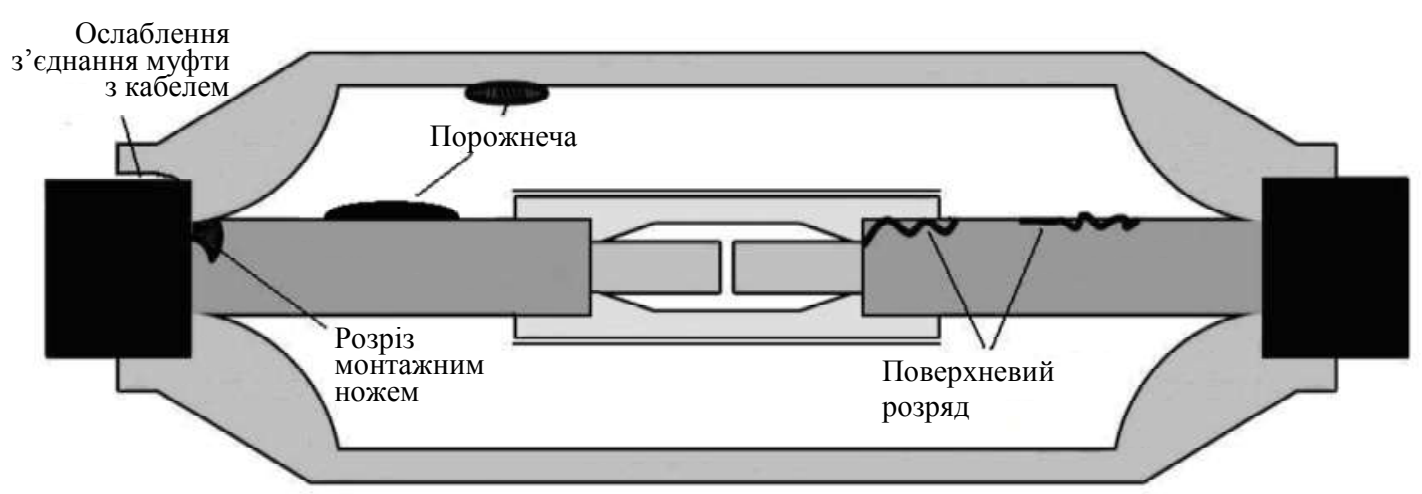

Рис. 2. Типові пошкодження в кабельних муфтах з екструдованою ізоляцією Джерело: розроблено авторами за даними [11].

Для оцінки стану ізоляції силових кабелів в умовах експлуатації застосовуються такі способи діагностики: традиційні (зазвичай руйнівні) і неруйнівні. Традиційні способи діагностики стану кабельних ліній дозволяють отримати інформацію про поточний стан ізоляції кабелів, але в більшості випадків призводять або до їх пошкодження, або до скорочення терміну служби. Неруйнівні способи діагностики, засновані на періодичному або постійному вимірюванні найбільш інформативних характеристик ізоляції, дозволяють отримувати інформацію про поточний стан ізоляції кабелів, не пошкоджуючи їі.

Перелік традиційних способів діагностики наведений в $[2 ; 3 ; 12]$. До них належать: вимірювання значення опору ізоляції мегомметром на напругу 2500 В та випробування випрямленою напругою. Для проведення профілактичних випробувань і діагностики стану силових кабельних ліній рекомендовано застосовувати один (або в комбінації) з таких видів випробувальної напруги: змінну синусоїдальну напругу частотою 50 Гц; змінну напругу прямокут- 
ної косинусоподібної форми частотою 0,1 Гц; випрямлену напругу постійного струму; змінну резонансну напругу автоколивань діагностичного вимірювального контуру; змінну напругу синусоїдальної або трапецеїдальної форми частотою 0,1 Гц.

До сучасних неруйнівних методів діагностики кабелів можна віднести: метод вимірювання часткових розрядів (ЧР); метод аналізу зворотної напруги в ізоляції силових кабелів; метод вимірювання струму релаксації в ізоляції кабелів із зшитого поліетилену; метод вимірювання кута діелектричних втрат; метод імпульсної рефлектометрії для локалізації низькоомних пошкоджень і імпульсно-дуговий метод для локалізації високоомних пошкоджень; метод контролю цілісності оболонки силових кабелів і визначення місць пошкодження в оболонках [13-14].

Метод вимірювання часткових розрядів (тобто мікророзрядів, які виникають в місцях неоднорідності ізоляції при робочій напрузі) дозволяє на підставі проведення вимірювань 3 визначенням величини, інтенсивності, напруги виникнення і гасіння ЧР визначити 3 досить високою точністю місце виникнення дефектів в кабельної лінії [15].

Метод вимірювання та аналізу зворотної напруги в ізоляції кабелів заснований на вимірюванні та аналізі залежностей від часу струму заряду ємності діагностованого кабелю постійною напругою (1-2 кВ), яка не руйнує ізоляцію кабелю, і відновлюючої (зворотньої) напруги в його ізоляції після короткочасного розряду кабелю. Ці залежності, що характеризують стан, ступінь старіння і вміст вологи в ізо- ляції силових КЛ, дають можливість оцінити ступінь старіння ізоляції за максимальною величиною зворотної напруги, швидкістю наростання зворотної напруги і за коефіцієнтами нелінійності.

Однією 3 інформативних характеристик стану ізоляції силових кабелів є величина тангенса кута діелектричних втрат ( $\operatorname{tg} \delta$ ) в ізоляції. Абсолютні значення $\operatorname{tg} \delta$, виміряні при напругах, близьких до робочих, а також їх збільшення при зміні випробувальної напруги і температури, характеризують якість вихідних діелектричних матеріалів і процесу виробництва кабелів. За результатами вимірювання $\operatorname{tg} \delta$ ізоляції кабелів в умовах експлуатації при різних випробувальних напругах і частотах також можна судити про стан і ступінь старіння ізоляції експлуатуючих кабелів. Для попередньої локалізації місць пошкоджень в силових КЛ найбільшого поширення набув імпульсний метод рефлектометрії (метод відбитих імпульсів - TDR). При використанні цього методу в КЛ надсилається зондуючий короткий низьковольтний імпульс і реєструється відбитий сигнал. За параметрами відбитого імпульсу можна оцінити наявність пошкоджень і неоднорідностей по трасі КЛ, тип неоднорідностей і відстань до них. 3 перерахованих методів найбільшу зацікавленість викликають метод вимірювання часткових розрядів та метод вимірювання та аналізу зворотної напруги, тому що їх сукупність дозволяє визначити переважну більшість проблем в кабелі. Характеристика цих двох методів наведена на рис. 3.

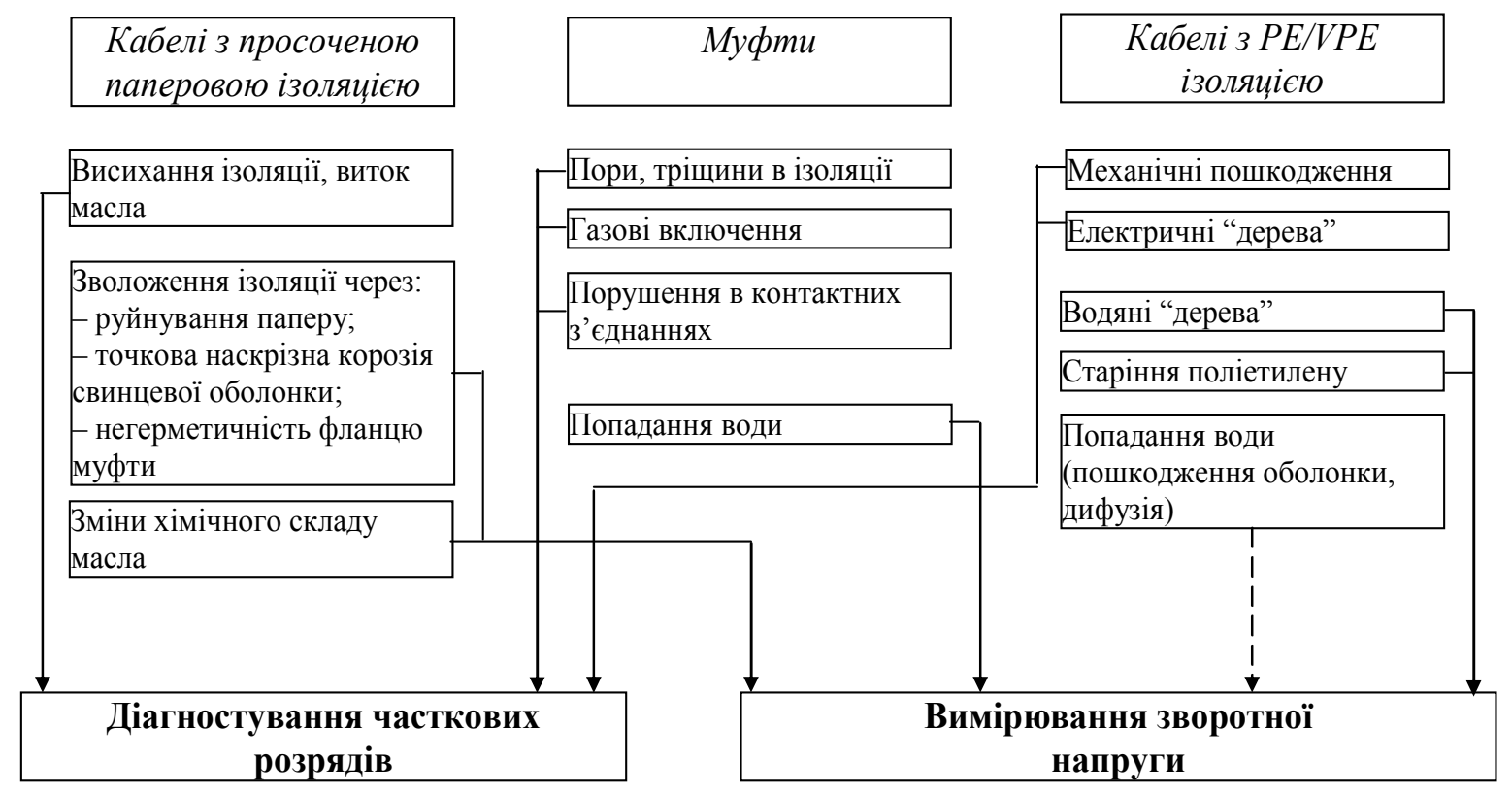

Рис. 3. Характеристика деяких методів діагностики кабелів Джерело: розроблено авторами.

Метод вимірювання та аналізу зворотної напруги найбільш широко був досліджений угорським професором Неметом на зразках кабелів 10 кВ з паперово-просоченою і полівінілхлоридної ізоляцією 3 
вимірюванням абсорбційних характеристик ізоляції після збудження поляризаційних процесів подачею постійної напруги 1 кВ [16]. Було встановлено, що вимірювання абсорбційних характеристик виявляють процеси старіння ізоляції кабелів набагато чутливіше, ніж традиційне вимірювання $\operatorname{tg} \delta$ на промисловій частоті. Процедуру діагностики кабелів 3 паперово-просоченою ізоляцією напругою до 35 кВ проводять за такою схемою (рис. 4): 1 фаза - заряд ємності кабелю постійною напругою 1 кВ протягом не менше 30 хв для рівномірного заряду всіх елеме- нтів ємності кабелю 3 вимірюванням величини струму заряду, що характеризує ступінь зволоженості ізоляції. 2 фаза - короткочасний розряд ємності кабелю протягом декількох секунд через розрядний опір; при цьому заряд, що міститься в “поляризаційній ємності”, який характеризує стан ізоляції кабелю, зберігається за рахунок дуже великої постійної часу розряду. 3 фаза - вимірювання часових характеристик відновленої (зворотної) напруги в процесі перезаряду ємності кабелю після закінчення короткочасного розряду кабелю.

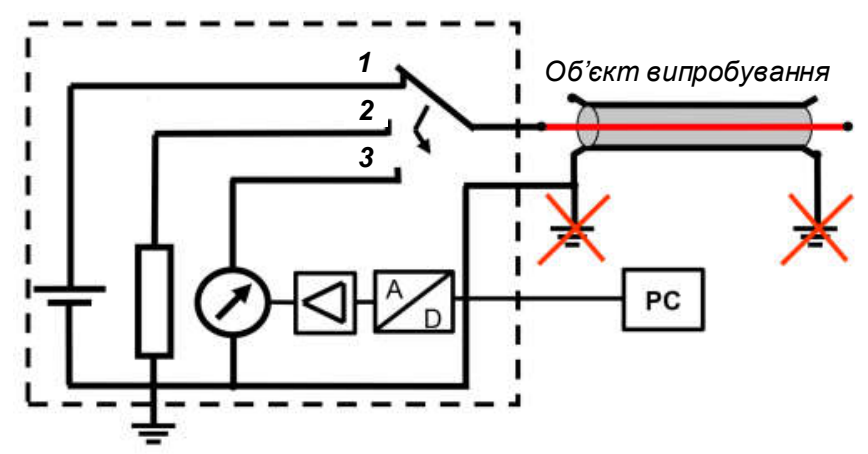

Рис. 4. Схема установки для вимірювання зворотної напруги:

1 - заряд 1800 c; 2 - розряд 5 с; 3 - вимірювання 1800 с

Джерело: розроблено авторами за даними [16].

Після закінчення процесу вимірювання зворотної напруги кабель повністю розряджається, і процедура діагностики повторюється за описаною схемою при напрузі 2 кВ. Надалі аналізуються отримані криві поворотної напруги, що характеризують стан і ступінь старіння ізоляції діагностованого кабелю, i визначаються такі характеристики: максимальна величина зворотної напруги; час досягнення максимальної величини зворотної напруги; швидкість наростання зворотної напруги. Визначаються також коефіцієнти лінійності по співвідношенню максимальних величин і швидкостей наростання зворотної напруги при двох величинах зарядної напруги (2 i 1 кВ). Чим більше коефіцієнти лінійності (діагностичний чинник) відрізняються від величин, характерних для “новоі” ізоляції, тим вище ступінь старіння ізоляції діагностованого кабелю.

За результатами діагностування КЛ з використанням такого методу можна оцінити:

- стан і ступінь зволоженості ізоляції кабелів і муфт за результатами вимірювання величини струму заряду, що характеризує інтенсивність процесів провідності в ізоляції, і зіставлення результатів вимірювання з раніше отриманими значеннями для діагностованої КЛ і особливо з результатами, характерними для нової ізоляції кабелів відповідного типу;

- інтенсивність процесів старіння (зволоження, термічне старіння ізоляції) за результатами визна- чення максимальної величини швидкості наростання зворотної напруги і коефіцієнта лінійності;

- стан і ступінь старіння ізоляції за підсумками порівняння результатів вимірювання зворотної напруги з раніше отриманими даними діагностується КЛ і з результатами, отриманими на нових кабелях відповідного типу, а також отримати додаткову інформацію про природу виявлених дефектів в ізоляції кабелів і причини можливого пробою кабелю при подальшій експлуатації.

Метод вимірювання часткових розрядів $\epsilon$ іншим перспективним методом визначення технічного стану силових КЛ. Частковим розрядом (ЧР) називають короткочасний розряд надмалої потужності, що виникає всередині або на поверхні ізоляції високовольтних кабелів. Одиночний ЧР не тягне за собою особливої небезпеки - це коротка подія, нездатна нашкодити кабелю. Але, виникаючи на регулярній основі, такі розряди призводять до руйнування ізоляції, і як наслідок, до короткого замикання.

В результаті ЧР спостерігаються такі явища: поява імпульсного струму; електромагнітне випромінювання в навколишнє середовище; світлове випромінювання; руйнування ізоляції і поява тріщин в ній. Найчастіше ЧР спостерігаються в місцях неоднорідності ізоляції, таких як вкраплення шлаків i домішок, повітряні порожнечі або крапельки рідини.

Виникнення ЧР в більшості типів ізоляції є абсолютно недопустимим, тому що це призводить до 
інтенсивного розкладання діелектрика і поширення дефекту. Так, для паперової ізоляції зазвичай повний пробій може відбутися через кілька місяців або навіть днів після виникнення ЧР. Таким чином, у багатьох поширених типах ізоляції необхідно виявляти ЧР при номінальній напрузі. Найбільшого поширення для вирішення цього завдання отримали електричні і акустичні методи. В основі групи акустичних методів лежить пошук і вимірювання характерних ультразвукових коливань, викликаних ЧР. Електричні методи виявлення часткових розрядів грунтуються на вимірюванні імпульсів струму в системі. При вимірюванні ЧР випробуваний кабель спочатку заряджається протягом декількох секунд постійною напругою, після чого за допомогою електронного ключа розряджається протягом десятих часток секунди через резонансну котушку. Це не викликає старіння або пошкодження ізоляції.

Вимірювання ЧР дозволяє визначати: величину і місце розташування ЧР по довжині КЛ; кількість ЧР в локальних (проблемних) місцях КЛ; напруга виникнення і гасіння ЧР; тангенс кута діелектричних втрат в ізоляції; електричну ємність.

Сукупності значень цих параметрів достатньо для отримання обгрунтованого висновку про технічний стан і про конкретні проблемні місця діагностованої КЛ.

Схема установки для вимірювання часткових розрядів наведена на рис. 5.

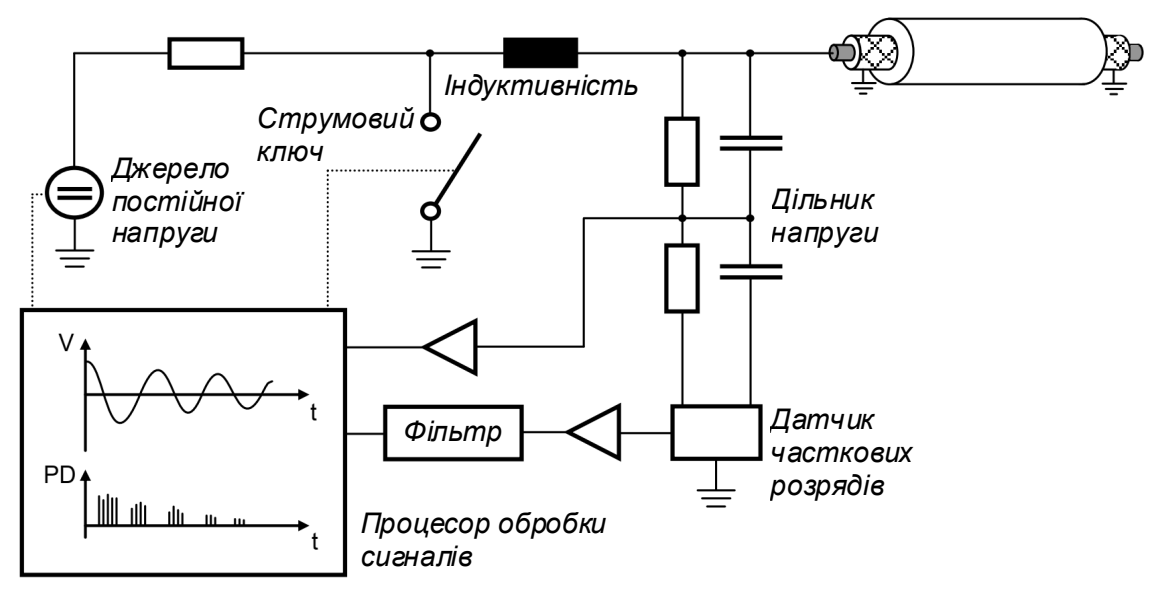

Рис. 5. Схема установки для вимірювання часткових розрядів Джерело: розроблено авторами за даними [16].

Причиною підвищеної уваги до методу реєстрації часткових розрядів (ЧР), при діагностиці електричної ізоляції силових КЛ в умовах їх експлуатації у складі СЕП військових аеродромів - його висока ефективність. По-перше, застосування цього методу, що має високу чутливість, дозволяє виявляти утворення ЧР в дефектних місцях на ранніх стадіях. Подруге, характеристики ЧР дозволяють здійснювати багатосторонню оцінку властивостей дефектів і характеру процесу ЧР. По-третє, метод дозволяє визначати як інтегральні властивості характеристик ЧР як безлічі розрядів, так і властивості одиничних розрядів. По-четверте, метод дозволяє безінерційно відображати явища розрядів в ізоляції.

\section{Висновки}

Проведений аналіз можливостей удосконалення засобів моніторингу технічного стану силових кабельних ліній систем електропостачання військових аеродромів показав наступне.

1. В процесі експлуатації силові КЛ піддаються комплексному впливу різних чинників, що може призвести до пошкодження кабелів при досягненні граничних значень характеристик ізоляції. Для попередження аварій на КЛ і розробки стратегії щодо ремонту або заміни силових кабелів 3 небезпечними дефектами чи з виробленим ресурсом ізоляції необхідно мати достовірну інформацію про їх поточний технічний стан.

2. Керівними документами передбачено проведення тільки періодичних вимірювань та випробувань КЛ, які, з одного боку, дають тільки імовірнісну оцінку імовірності безвідмовної роботи силових КЛ в період між вимірюваннями (випробуваннями), а $з$ іншого боку, можуть самі стати причиною виходу лінії з ладу. Тому актуальним є впровадження неруйнівних засобів моніторингу технічного стану силових КЛ СЕП військових аеродромів, спрямованих на підвищення надійності функціонування систем забезпечення польотів авіації.

3. Проведений аналіз показав доцільність використання засобів моніторингу технічного стану силових КЛ на основі методу вимірювання часткових розрядів та методу вимірювання й аналізу зворотної 
напруги, тому що їх сукупність дозволяє визначити переважну більшість проблем в КЛ, своєчасне усунення яких забезпечить підвищення надійності функціонування систем забезпечення польотів авіації.

4. Засоби моніторингу технічного стану силових КЛ на основі методу вимірювання часткових розрядів дозволяють найбільш ефективно визначити такі пошкодження, як висихання ізоляції та виток масла в кабелях з паперовою просоченою ізоляцією, утворення пор, тріщин, газових включень та пору- шення контакту в 3'єднувальних муфтах, а також механічні пошкодження та електричні пробої в кабелях $з$ поліетиленовою ізоляцією.

5. Засоби моніторингу технічного стану силових КЛ на основі методу вимірювання зворотної напруги є найбільш ефективними для визначення зволоження ізоляції кабелів 3 паперовою просоченою ізоляцією та зміни хімічного складу масла в них, попадання води в з'єднувальні муфти та в кабелі з поліетиленовою ізоляцією.

\section{Список літератури}

1. Визначення очікуваного впливу противника на системи електропостачання аеродромів у ході ведення бойових дій та рекомендації щодо їх відновлення / С.М. Новічонок, О.А. Усачова, О.Б. Куренко, А.О. Романюк, І.В. Терентьєва // Збірник наукових праць Харківського національного університету Повітряних Сил. - 2018. - № 4(58). - С. 80-88. https://doi.org/10.30748/zhups.2018.58.11.

2. Наказ Мінпаливенерго України "Правила технічної експлуатації електроустановок споживачів № 258 від 25.07.2006". - $168 \mathrm{c.}$

3. Наказ Мінпаливенерго України "Норми випробування електрообладнання СОУ-Н ЕЕ 20.302:2007 № 13 від 15.01.2007”. - $262 \mathrm{c}$.

4. Comparison among different diagnostic systems for medium voltage cable lines / V. Colloca, A. Fara, M. Nigris, G. Rizzi. - Paris: CIRED. -109 p.

5. Hoff G. Correlation Between Return Voltage and Relaxation Current Measurements on XLPE Medium Voltage Cables / G. Hoff, H.G. Kranz // Eleventh International Symposium on High Voltage Engineering. - London, 23-27 August 1999. P. 102-105. https://doi.org/10.1049/cp:19990896.

6. PD measurements on-site using oscillating wave test system / E. Gulski, J.J. Smit, P.N. Seitz, J.C. Smit // Institute of Electrical and Electronics Engineers. - 1998. - № 2. - P. 420-423.

7. Advanced solution for on-site diagnosis of distribution power cables / F. Petzold, H. Schlapp, E. Gulski, P. Seitz, B. Quak // Dielectrics and Electrical Insulation. - 2008. - № 15. - P. 1584-1589.

8. Bing J. Mobile monitoring of underground cable systems / J. Bing. - Washington: University of Washington, 2003. - 91 p.

9. Reder W. Reliability Centered Maintenance for Distribution Underground Systems / W. Reder, D. Flaten // Electrical and Electronics Engineers. - 2000. - № 1. - Р. 551-556.

10. Лагутін Г.І. Вдосконалення способів релейного захисту силових трансформаторів в системах електропостачання військових аеродромів, що залучаються для потреб ООС / Г.І. Лагутін, А.І. Кудрявський, С.М. Хабоша // Збірник наукових праць Харківського національного університету Повітряних Сил. - 2019. - № 2(60). - С. $126-132$. https://doi.org/10.30748/zhups.2019.60.16.

11. Jean C. Characterization of real power cable defects by diagnostic measurements / C. Jean. - Atlanta: Georgia Institute of Technology, 2008. $-292 \mathrm{p}$.

12. СОУ-Н ЕЕ 20.304:2009. Норми випробування силових кабельних ліній до 500 кВ [Електронний ресурс]. - К.: КВІЦ. - 2009. - 50 с. - Режим доступу: http://online.budstandart.com/ru/catalog/doc-page?id_doc=26445.

13. Overview of cable system diagnostic technologies and application / R. Hartlein, N. Hampton, J.C. Hernández, J. Perkel // The National Electric Energy Testing Research and Applications Center. - 2006. - № 4. - P. 211-212.

14. Harrold R. Ultrasonic Sensing of PD Within Large Capacitors / R. Harrold // Electrical Insulation Magazine. - 1993. № 3(9). - P. 21-28.

15. Шакиров Э.И. Анализ неразрушающих методов диагностики кабельных линий [Електронний ресурс] / Э.И. Шакиров // Молодой ученый. - 2019. - № 9(247). - С. 108-111. - Режим доступу: https://moluch.ru/archive/247/56907/.

16. Офіційний сайт NEWS.ELTEH.RU. Кабели 10 кB с бумажно-пропитанной изоляцией. Неразрушающий метод диагностики. - Режим доступу: http://www.news.elteh.ru/arh/2005/35/16.php.

\section{Відомості про авторів:}

\section{Лагутін Геннадій Іванович}

кандидат технічних наук доцент

начальник кафедри

Харківського національного університету

Повітряних Сил ім. І. Кожедуба,

Харків, Україна

https://orcid.org/0000-0002-6337-1357

\section{Information about the authors:}

\section{Hennadiy Lahutin}

Candidate of Technical Sciences Associate Professor

Head of Department

of Ivan Kozhedub Kharkiv

National Air Force University,

Kharkiv, Ukraine

https://orcid.org/0000-0002-6337-1357 


\section{Хабоша Сергій Миколайович}

старший викладач кафедри

Харківського національного

університету Повітряних Сил ім. І. Кожедуба,

Харків, Україна

https://orcid.org/0000-0002-9314-1536

e-mail: haboshasergei76@gmail.com

Перепелиця Владислав Олександрович

курсант

Харківського національного університету

Повітряних Сил ім. І. Кожедуба,

Харків, Україна

https://orcid.org/0000-0002-4200-9519

\section{Кулинич Ігор Ігорович}

старший науковий співробітник

науково-дослідного відділу

центру імітаційного моделювання

Національного університету оборони України

ім. I. Черняхівського,

Київ, Україна

https://orcid.org/0000-0001-5543-842X

Солдатенко Ігор Олегович

начальник відділу управління регулювання

державної авіації України,

Київ, Україна

https://orcid.org/0000-0001-5199-5499
Serhiy Khabosha

Senior Instructor of Department

of Ivan Kozhedub Kharkiv

National Air Force University,

Kharkiv, Ukraine

https://orcid.org/0000-0002-9314-1536

e-mail: haboshasergei76@gmail.com

Vladislav Perepelytsya

Cadet

of Ivan Kozhedub Kharkiv

National Air Force University,

Kharkiv, Ukraine

https://orcid.org/0000-0002-4200-9519

Igor Kulinich

Senior Research Associate

of Scientific Research Department

of Simulation Center of Ivan Chernyakhivsky

National University

of Defense of Ukraine,

Kyiv, Ukraine

https://orcid.org/0000-0001-5543-842X

Ihor Soldatenko

Head of the Regulatory Department

State Aviation of Ukraine,

Kyiv, Ukraine

https://orcid.org/0000-0001-5199-5499

\section{НАПРАВЛЕНИЯ СОВЕРШЕНСТВОВАНИЯ СРЕДСТВ МОНИТОРИНГА ТЕХНИЧЕСКОГО СОСТОЯНИЯ СИЛОВЫХ КАБЕЛЬНЫХ ЛИНИЙ СИСТЕМ ЭЛЕКТРОСНАБЖЕНИЯ ВОЕННЫХ АЭРОДРОМОВ}

Г.И. Лагутин, С.Н. Хабоша, В.А. Перепелица, И.И. Кулинич, И.О. Солдатенко

В статье проведен анализ причин ухудшения технического состояния силовых кабельных линий, возникающих в системах электроснабжения стацуионарных военных аэродромов, и существуюших средств оцченки состояния изоляциии силовых кабелей в условиях эксплуатации. На основании проведенного анализа рассмотрены перспективные средства неразрушающего мониторинга технического состояния силовых кабельных линий систем электроснабжения военных аэродромов, способствующче повышению надежности функичонирования систем обеспечения полетов авиации.

Ключевые слова: стационарный аэродром; системы электроснабжения; силовые кабельные линии; мониторинг технического состояния.

\section{DIRECTIONS OF IMPROVING THE MEANS OF MONITORING THE TECHNICAL CONDITION OF POWER CABLE LINES OF MILITARY AIRFIELDS POWER SUPPLY SYSTEMS}

H. Lahutin, S. Khabosha, V. Perepelitsa, I. Kulinich, I. Soldatenko

During operation, power cable lines are exposed to a complex effect of various factors, which can lead to damage to the cables when reaching the limit values of insulation characteristics. In order to prevent accidents on cable lines and to develop a strategy for repairing or replacing power cables with dangerous defects or with the produced insulation resource, it is necessary to have reliable information about their current technical condition. The guiding documents provide only for periodic measurements and tests of cable lines, which, on the one hand, give only a probabilistic estimate of the probability of failure of power cable lines in the period between measurements (tests), and on the other hand, can cause the line to fail. Therefore, the introduction of non-destructive means of monitoring the technical condition of power cable lines of military airfields power supply systems, aimed at improving the reliability of aviation flight systems. The analysis showed the feasibility of using means of monitoring the technical condition of power cable lines based on the method of measuring partial discharges and the method of measuring and analyzing the reverse voltage, because their combination allows to identify the vast majority of problems in cable lines, timely elimination of which will increase reliability. Means of monitoring the technical condition of power cable lines based on the method of measuring partial discharges allow the most effective detection of such damage as drying of the insulation and oil leakage in cables with paper impregnated insulation, formation of pores, cracks, gas inclusions and contact in couplings, and as well as mechanical damage and electrical breakdowns in cables with polyethylene insulation. Reverse voltage measuring devices are the most effective in determining the moisture content of paper impregnated cable insulation and changes in the chemical composition of the oil, the ingress of water into the couplings and the cable with polyethylene insulation.

Keywords: stationary airfield; power supply systems; power cable lines; technical condition monitoring. 